\title{
The Court, FCC and Internet Policy: Partly with South Korea
}

\author{
Kiyoung Kim \\ Department of Law, Chosun University, Gwangju, South Korea \\ Email: kiyoungkim@chosun.ac.kr
}

How to cite this paper: Kim, K. (2017). The Court, FCC and Internet Policy: Partly with South Korea. Beijing Law Review, 8, 373-396.

https://doi.org/10.4236/blr.2017.83021

Received: August 12, 2017

Accepted: September 26, 2017

Published: September 29, 2017

Copyright $\odot 2017$ by author and Scientific Research Publishing Inc. This work is licensed under the Creative Commons Attribution International License (CC BY 4.0).

http://creativecommons.org/licenses/by/4.0/

\section{(c) (i) Open Access}

\begin{abstract}
The paper aims to explore the contour of internet regulation with a thread of Brand $X$, which navigates through constitutionalism, separation of powers, as well as business and economic or political implications enshrined behind it. An exemplary insight with the Korean case was adverted that could lead to the comparative perspective of internet law and regulation for the future research. The research was conducted by employing qualitative investigation, mainly relying on textual analysis and documentary examination. The outcome of research generally corroborates with our assumption that i) the increasing administrative state will variegate the traditional interplay of three branches, ii) expert bureaucracy stands at the core of policy shaping because of the necessary new concept of market and policy specialization, iii) the role of US government is not only pioneering, but also influential as a regulator, but comparatively with differing national jurisdictions if not a negligible implications on the international competition or even conflict.
\end{abstract}

\section{Keywords}

Net Neutrality, Internet, Chevron Rule, FCC, Judicial Deference,

Three Branches, Public Policy, Market Regulation, Equal Access

\section{Introduction}

Given the transformation of global society into the world of internet, global jurisdictions are facing the challenge how they regulate the market or make policies to deal with various national goals including the equal protection of law and to ensure a level playing field for the market participants. The paper is intended to problematize the unique feature of internet policy with delicacies and characteristics that will illustrate some implications of constitutionalism, expertly ad- 
ministration, separation of powers principle, creative economy and policy response. The research questions are addressed how and to what extent this new area of industry affects the traditional constitutionalism involving related interest holders, i.e., consumer, businesses, and nations within the increasing internet community. The dealings are never exhaustive or even just illustrative, but hoped to portray the contour of issues inherent within the internet policy that could motivate a future research with the specific focus and diversified ends of individual researcher's concern. The method of this research study employed the qualitative approach that the author's discourse and theme were constructed on the data and meanings generated mainly from the examination of literature and textual analysis.

I will begin my exploration with the presentation of general description and characteristic of internet in chapter 2 . The next chapter introduces with the case, titled Brand X, which is one of important Supreme Court decisions on the net neutrality principle in US. The case is significant to affirm a wider discretion of FCC in the battle over network neutrality in US. The fourth chapter highlights the impact of case on the government. Given the Chevron standing, the subsequent policy arguments have been led by FCC, President, business enterprises, consumer or civil cause organization, Congress and part of judiciaries not directly involved with the issue of classification. In the fifth chapter, I will show that the consequence of Court ruling ineluctably will lead to the enhanced policy making role on the part of FCC and even South Korea, but indirectly with the comparative difference between two countries. In the sixth and seventh chapters, several points of legal response can be surveyed, and largely from the comparative view of Korean law on internet regulation. The role and responsibility of FCC had been challenged by the liberalist cause in US and new enactment on the KCC around 2007 had been critiqued by scholars of concern. That would not be merely shenanigan, but can provide an example for the federal or state government. In the last two chapters, I will elicit that the net neutrality involves a square aspect of communal interests and impact on the policy areas. It also will be proposed that the development of internet market and attendant regulation need to liaison our beliefs and thoughts with the civic values.

\section{General on the Internet}

The internet is one of most influential invention which affects our civic lives. The mode of interaction is typical as differs from the traditional telecommunication services, such as telephone, TV, or radio. The internet usually is connected to a PC for public use and now enhanced applications are used in the form of hand-carried Smart Phone. The invention had made a significant impact society-wide and one of important achievement to bring a new concept of industrialization (Crawford, 2014: pp. 10-15; Lachman, 2009: pp. 8-12).

In terms of political viewpoint, the internet would bring the kind of many 
important transformations and international conflict (Owen, 2015). For example, the election mode may acknowledge the benefit of internet that on-line votes may be made official in some context of polls. The concept of e-government has recently turned popular that now is being considered as necessary and indispensable or a specimen of democratic progress in the underdeveloped countries. The cyber war had been reported occasionally as a new form of terrorism and indirectly demonstrates the significant impact of internet and its security.

In terms of civil or social lives, it is notorious that the current public had spent much of his or her time to interact with the internet mode of communication (Nunziato, 2009: pp. 9-12). While the advent of film in early of this century and subsequent development of TV into home use would be an important turnpike to the wider scope of popular democracy, the internet could well follow to continue dismantling the traditional area of prestige and enclaves of ruling class. The freedom of expression would be more in strong impact with the kinds of open access trend over various sectors of society and the internet space has been an important forum of public debate, say, source to gather information as well as the avenue of social or public interchange. The on-line education has grown to dispense a levels of academic degrees in the universities, and one way of scholarly exchange through submission of journal articles or teleconference on the internet basis. Perhaps the contemporary citizens would spend more time through the internet or Smart-Phone activities than viewing TV, which is distinct from the decades ago.

In terms of ethic, law or regulatory concerns, the internet phenomenon requires policy makers to respond actively with the challenges, including-but not limited to the invasion of privacy-new mode of crimes, new pattern of copyright or trade secret issues, new mode of businesses or corporate issues as well as new concept of property rights and public justice involving net neutrality (Kim, 2015a). The context of evolution over legal theory or regulatory framework may differ across the countries since the social compassion or national culture would not be same depending on factors or traits. That is true although the internet represents a ubiquitous commonality through universal exposure or the telecommunication technology is on the same root basis. For example, Koreans view that the owners of telecommunication service shall be defined as "common carrier" which should be neutral and basic other than the commercial entities so as not to exploit the internet use to their prurient interest. In Korea, there would be three major service providers in terms of telecommunication infrastructure, i.e., SK, LG and KT. On the other hand, the federal telecommunication act in the US would define such major providers as information service other than common carrier, which shall profit depending on their competitiveness within the market and according to the market principle (Lee, 2015). To say, the businesses categorized as information service can impose a fare of internet use which will be based on the time of use. 


\section{NCTA v. Brand X}

The Brand $X$ is one of important Supreme Court decisions on the net neutrality principle in US (National Cable and Telecommunication Association v. Brand X Internet Service, 2005). As briefed on the contemporary mode of livelihood for the citizenry, the internet or cyber space has a scale of influence that had been transformative, perhaps at fantasy on the science and business community, and steadily into the consumers. We have enjoyed a radio, television, and now the kind of monstrous internet device as our book shelves, e-repository of articles, government documents, and video games, social e-media and e-newspaper, wireless mobile phone service, music of y-tube, through the personal webpage. Besides the medical and space science, the sectors not only received a stellar attention of public, but even amount to require a paradigm change over the social science and humanity. The context had been sketched with my limited exposure of daily lives above so that I can have a due curtail here. Naturally, the internet is now challenged from the policy considerations as principled in terms of net neutrality (Tim, 2003; Yoo, 2005). The net neutrality, as a matter of definition, requires [that] the internet service providers and governments should treat all data on the Internet equally, not discriminating or charging differently by user, content, site, platform, application, type of attached equipment, or mode of communication. Generally, the policy issues are to be narrowed with the government, but not the case in this definition. This lends a soft prism of framework, but implies the attribute of issue impressed with the high impact and spread through the public than any other businesses. A policy position or determination of specific controversy permeates the public domain in any pounding consequence, but involves a difficult or callous technical aspect of policy options as a challenge.

This backdrop might create a feel and destination of majority court in Brand $\mathrm{X}$, so that it ultimately deferred to the decision of Federal Communications Commission (hereinafter referred to as FCC) on the Chevron rule (NCTA v. Brand X, 2005). As a numbered webpage of Wikipedia implies, the net neutrality would be any contentious issue in US, partly because the economy is most advanced and also because a cult over the global community had been shared. Nevertheless, the issue entails a public aspect that we could see a general discussion on the principle of net neutrality as a matter of livelihood and public justice. Scholarly voice to propose the net neutrality normally includes the consumer advocates, human rights organizations, online companies and technology companies. The net neutrality opposing group would arise in the diverse context, principally big companies, notable technologists, President Obama, several civil right groups (NYT Editorial Board, 2014). As seen in above definition, the issue could be truncated into an alignment of providers and governments against the consumers. That is vastly true, but the issues-as hinted from participant groups-more precisely speaking, would involve diversified policy interests. The issues of small business and civil views of complicated challenge can have their 
own cause. Eric, a Google CEO, could be proper with this challenging environment, whose view is modest and eclectic "while Google views that similar data types should not be discriminated against, it is okay to across data types..." The statement of former FCC chief of policy development, R. Pepper shows a basic tenet of both arguments "The supporters of net neutrality regulation believe that more rules are necessary... without greater regulation, service providers might parcel out bandwidth of services, creating a bifurcated world in which the wealthy enjoy first class internet access, while everyone else is left with slow connections and degraded content." (Nate, 2009).

If given as a summary of FCC in Figure 1, the consequence of majority opinion has left an interpretation of federal communication act and classification of internet service providers within the discretion of FCC. It specifically confirmed that the Chevron rule must be applied if the provisions are vague even when the precedent of same court (in this case, ninth division of federal circuit court) guide as a binding power (NCTA v. Brand X, 2005; Chevron USA, Inc. v. Natural Resources Defense Council, Inc., 1984). Since there is no precedent of Supreme Court on the subject matter, the Ninth Circuit would search any same or co-equal rank of court decision and apply it, which, however, was rejected on the ground that the stare decisis effect could be bought only when the agency interpretation is "unambiguous to conclusively match up to create a certain rule with the statutory provision" in terms of Chevron. Given if the statutory provision is vague as an original text, the FCC could read it in other way later on different situation or newly emerging challenges that is the rule of Supreme Court now at hand. This has a merit from viewpoints: i) the Congress and FCC are ensured of an equal rank of brother branch with the Supreme Court; ii) the Executive within the US Constitution is unitary in line authority and hierarchy that the FCC is also equal with the head of Executive in terms of decision making exceeding that of federal appellate courts; iii) the Supreme Court suggests that more adequate
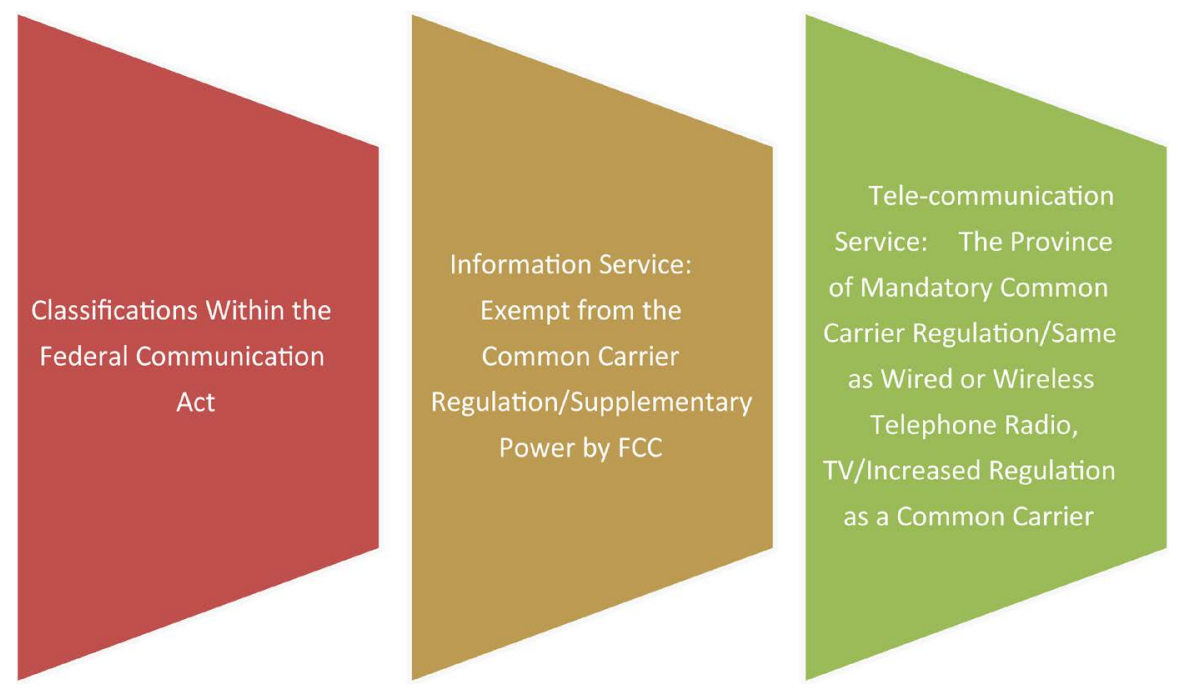

Figure 1. Classification of FCA. 
policy making body for the interpretation and enforcement of statute would be FCC than lower courts, which retains and exercises expertise and wealth of traditions or on the concerned regulatory field. This ruling, however, provokes the kind of general questions, if the FCC is such robust to consider all facets of factors or variants beyond the law and national economy. The lobbying groups perhaps would be a larger corporation on the field and the economic impact would be their prime concern in normal countenance. Nevertheless, my reiteration is relevant here that the net policy brings an omnipresent effect on the current mode of livelihood as well as social beings, or even frames. Then, the courts would be a more adequate forum to argue on the spectrum of consequences brought by the net policy. So it is interesting that the Ninth Circuit also relied on the legal rules that the stare decisis is determinative to dispose the case (Brand $X$ Internet Service. v. FCC, 2003).

That is an essential of common law system that the common law judges could not betray ultimately. Unfortunately, however, the rapid progress on the related science and demand of business world would create earning a damage if the proper policies will not follow back succinctly or in timely fashion. We may remain, however, as a commoner or kind of nobility like the judges, to be shared with the enjoyment and pleasure of internet development. As I have argued elsewhere, the certainty, stability and predictability is an essence of noble class that the judges generally pursue to serve the community in their stewardship, but could possibly be biased, in terms of internet regulation, with anew value of competition and complicated tech-business.

The kind of legal ideals would be intrigued with the formalism and structural certainty as Justice Scalia argued in his dissenting opinion (NCTA v. Brand X, 2005). I agree that the Supreme Court might not be scrupulous with its reasoning and rhetoric. First, the Supreme Court had not needed to mention on the stare decisis effect of Ninth Circuit. Since the Supreme Court is legitimate to overrule the lower court's ruling, only two ways could stand if it liked to deny the entitlement of Chevron deference, and the Court might advance to specifically illuminate the right or permissible interpretation of provisions or if the Chevron rule duly governs the controversy at hand. If beyond this simplified response as the Supreme Court here, it would create an unnecessary excess of rules on the stare decisis generally or on the Chevron rule narrowly. This could lead to new agency reversal rule, as he coined, which only effects to increase a burden of defense on the Court in future cases. Second, his argument on the possible abuse of agency power to interpret statute would imply his worry that could derelict the finality of judiciary or general higher role of judicial supervision of federal agencies (2005). Structurally, then, would the Court differ between the judicial control of agencies action and balance of constitutional ranks of branches, and can go controversial given the lower courts being subjected to their organizing and status act. I seem to consider the court strength as a public forum on multifaceted policy considerations, but the national agenda of this kind would highly 
be challenging to create the paradigm of market that the FCC would likely be more competent to enjoy the Chevron deference (Weil, 2014). Since the dissenting opinion had not included a specific mention on the merit of subject matter, it is uncertain how it impacts the net policy in US. If the lower court judgment needs not to be sustained as a rule-suggested that it should be overturned and practically same with the majority opinion-the dissenting opinion seems to part with the net neutrality that the providers would be regulated at more extent.

In this case, the Supreme Court was called upon to determine on the statutory meaning of "telecommunications service" and "information service" defined in the 1996 congressional act (Telecommunication Act of 1996). The FCC has exercised a subject matter jurisdiction, which concluded that cable companies to sell the broadband internet service does not fall within the classification of telecommunication service under the act, and "hence are exempt from the mandatory common carrier regulation under the Title II" (Berkman, 2014). The issue in this case is whether the determination of FCC could survive as a lawful construction of FCC under the rule of Chevron. The Broadband in this case provides a high speed connection service distinct from the traditional means "dialing up" to local phone facilities (Staff, 2014).

The case is the first Supreme Court case that deals with the FCC action on net regulation, and had centered on the crucial stage of technology change from dial-up to high speed broadband or cable network. The case is significant to affirm the wider discretion of FCC in the battle over network neutrality in US (Kim, 2014a). As seen, the Court overruled the United States Court of Appeals that Chevron rule must be applied other than stare decisisprinciple unless the Court found the statute unambiguous under Chevron. The judgment, by upholding the FCC's determination, brought a limited scope of telecommunication service excluding such competing internet service providers (ISPs) like Brand $X$. It was remanded for further review of Ninth Circuit (Brand X Internet Service v. FCC, 2006). According to the Supreme Court ruling, a scope of ISPs became to be denied access to the cable and phone wires to provide home users with the competing internet service, implicating an impact of internet market, for example, more competition-based information service, new class and profit paradigm of telecommunication service, ensuing merger and acquisition and so. The net policy in US has a history in time line with several important stages (WorldCom, Inc. v. FCC., 2001; Verizon Communications Inc. v. FCC, 2002).

In 2004, FCC announced a set of non-discrimination principles, and urged network freedom without regulation (Crenshaw, 1988). The four freedoms specified by Powell, then Chairman of FCC included i) freedom to access content, ii) freedom to run applications, iii) freedom to attach devices, iv) freedom to obtain service plan information. The network freedom and neutrality principle was willed as shown in early 2005 Madison River Case, and did not fine Madison River Communications (Powell, 2004). It did not confirm that FCC would 
remain entirely free of regulation since the dispute has been disposed in settlement than formal finding. Immediately over years, the new technology change has necessitated a new policy impacting on the competitive local exchange carriers (CLEC), dial-up connection and digital subscribe line (DSL). In 2004, the Court of Appeals decided on the unbundled network elements (UNEs) for incumbent local exchange carriers and competitive local exchange carriers, and voided a USTA ruling on the FCC's authority to enforce rules requiring telephone operators to unbundle certain parts of their networks at regulated prices (US Telecom Assn. v. FCC., 2002). The decision obviously chilled the FCC's net neutrality and network freedom principle, and the consequence had been a significant injury and collapse of CLEC (Brauer-Rieke, 2009). We generally see that broadband services have two important sorts, cable service and DSL, in terms of public regulation and according to the net technology. The former has historically been free of regulation with the classification of information service while the DSL was subject to the extent of regulation as a telecommunications service. In 2005, the FCC announced important new principles conditioning the Network Freedom and neutrality on the concept or due requirement of law and public regulation. It consisted of four net neutrality principles as of voluntary nature (FCC, 2005). For example, it included that consumers are entitled to access the "lawful" Internet content of their choice, to run applications and services of their choice, subject to the needs of "law enforcement." It also emphasized the market competition to the interest of consumers (FCC, 2006). Shortly after the Supreme Court decision was rendered, representatives from several major US corporations and the federal government publicly addressed four important philosophies of US Internet services in 2006-the nature of free market forces, the public interest, the physical and software infrastructure of the Internet, and new high-bandwidth technologies (Brauer-Rieke, 2009).

\section{Subsequent Development within Three Branches}

Given the Chevron standing, the subsequent policy arguments have been led by FCC, President, business enterprises, consumer or civil cause organization, Congress and part of judiciaries not directly involved with the issue of classification. If the majority and dissenting opinions are practically same in effect, we can view such serious aftermath involving the advocacy or criticism on net neutrality as a due consequence that the future Court has to be more attentive. If the dissenting opinion is viewed to support more than increased role of Court on net policy, the consequence may be a basis to critique the majority court. Nevertheless, FCC actions after the 2005 decision are generally considered as to be strong, in terms of market regulation, to various interest groups.

Over the next few years, FCC tried on several rulings to elucidate what the net policy was meant practically. In August 2008, the FCC made its first Internet network management decision upholding a complaint against Comcast, which alleged to ascertain as Martin, FCC chairman, mentioned, "the order was meant 
to set a precedent, that Internet providers and all communications companies could not prevent customers from using their networks the way they see fit, unless there is a good reason" (Hansell, 2008). However, the FCC's 2008 ceaseand-desist order against Comcast was denied by the US Court of Appeals on the ground that FCC has no power to regulate any Internet provider's network, or the management of its practices. It found that FCC lacked the authority under Title One of the Communications Act of 1934, to force ISPs to keep their networks open, while employing reasonable network management practices, to all forms of legal content (Cheng, 2009; Communications Act, 1934; McCullagh, 2010). The case seems to underscore a rigorous standard of review concerning FCC's power although the Court had deferred to Chevron rule within the policy area for the classification and formulation of market structure. The FCC also employed a soft nature of policy such as spectrum auction, and President or major companies, such as Google, had interplayed to develop the net market. In 2008, FCC auctioned off the $700 \mathrm{MHz}$ block of wireless spectrum in anticipation of the DTV transition, and Google promised to respond with four conditions which were broadly similar to the FCC's Internet Policy Statement. In 2009, FCC reaffirmed its basic policy through a series of proposal in the public forum that would prevent telecommunications, cable and wireless companies from blocking certain information on the Internet, for example, Skype applications and required the transparency principle that ISPs disclose all their policies to customers. It also was principled that net neutrality shall apply in the same fashion both to wireless and wireline services (Ruane, 2009). Importantly in 2010, FCC had issued a mandatory nature of FCC Open Internet Order 2010 to align its policy and experience with the needs of market and public. It basically bannedcable television and telephone service providers from preventing access to competitors or certain web sites such as Netflix (Eveleth, 2014). A set of 6 net "neutrality principles" were announced by FCC in 2010, which provides concerning i) transparency ii) MO blocking iii) level playing field iv) network management v) mobile vi) vigilance. The network freedom and neutrality had been substantiated with the increasing profile of internet market (Kang, 2010). For example, the level playing field is guaranteed of consumers and innovators, which requires a ban on unreasonable content discrimination. On the other, so-called "pay for priority" arrangement, involving fast lanes for some companies but not others, was allowed-hence did not keep ISPs from charging more for faster access. The measure can be toned with the majority court that allowed a wide latitude of regulation, but was contended in Verizon (2014). The Court vacated portions of the FCC Open Internet Order 2010, and found that it relinquished its right to regulate the broadband providers-classified under the Title of the Communication Act of 1934 as "information service" as seen in 2005 decision-since the authority to impose an order should be limited to common carriers. The OIO 2010 was critiqued by the net neutrality advocates over price competition, and the case is considered of shrinking impact by limiting the FCC authority to 
impose it on the scope of common carriers business. As the service providers were not identified as "common carriers," the FCC authority had narrowed. However, the court agreed that FCC can regulate broadband and may craft more specific rules that stop short of identifying service providers as common carriers (2014).

The subsequent development upon Brand $X$ has implications to confirm our assumption that i) the internet market has been evolutionary and volatile in terms of public policy and regulation ii) sensitively intertwined with policy environment with their wide influence on various aspect of human activities and existence iii) the laws and policies would correspondingly come newly emerging and modifying. Hence, the majority opinion can have a merit by respecting the determination of FCC on the Chevron rule, which allowed a wide latitude of policy measure on part of FCC and practically brought the effect, "wait and see," on behalf of its supervisory role. The dissenting opinion, by calling upon the clarity of majority opinion and against the arbitrary ruling of FCC-had hinted on the importance of structural balance among the players involved, which hopefully could prevent a FCC's frivolous measure inconsistent with the previous position. A public voice on the issue may diverge. For example, as a response to the DC Circuit Court's decision, a dispute developed as to whether net neutrality could be guaranteed under existing law, or if reclassification of ISPs was needed to ensure net neutrality (Hu, 2014). Wheeler and President Obama would have a separate view that President Obama, supported reclassifying ISPs as common carriers under Title II of the Communications Act of 1934, while FCC argued for the authority, under Section 706 of the Telecommunications Act (1996), to regulate ISPs. With a series of action over the year of 2014, on November 10, President Obama recommended that FCC reclassify broadband Internet service as a telecommunications service in order to preserve net neutrality. The development tended to get embroiled with the kind of interbranch power game and challenges with the supervision and collaboration given the difficulties and complicacies as a public issue. Actually on February 19, 2014, FCC announced plans to formulate new rules to enforce net neutrality while complying with the court rulings (Nagesh, 2014). Interestingly, on January 16, 2015, Republicans presented legislation, in the form of a US Congress HR discussion draft bill, that makes concessions to net neutrality, but prohibits FCC from accomplishing the goal or enacting any further regulation affecting ISPs. Along the progress, it echoes that the constitution is any final touchstone to integrate various arguments and policy disagreement as FCC chairman, Tom Wheeler, commented, "This is no more a plan to regulate the Internet than the First Amendment is a plan to regulate free speech. They both stand for the same concept" (Lohr, 2015; Gross, 2015).

\section{Consequence and Influence: Partly with Korea}

The Court opinion would incur a remedial measure of FCC on vast of net poli- 
cies involving the neutrality and commercial freedom because the Court had ascertained the principle of deference on Chevron rule (Kim, 2014b). The power and discretion turned to be more political than normative, and the latitude of FCC would deserve a public interest. With respect to less of judicial supervision, FCC had adopted new policy initiative by 3 to 2 vote in 2014, in which the content businesses will be provided with a higher speed of telecommunication service (M.H, 2014). This would well create a condition of market on more competitive basis that the market principle and social justice or public utility and goodness would be honed in regulating the internet service (Kim, 2015). The market, however, will seem to be regulated on the fee basis that more paid information service will be legally guaranteed with a quality service. The telecommunication service, defined as common carrier and subject to rigorous regulation for public goodness, would welcome the policy as a new revenue source. On the while, the information service, especially new entrants into the market, would be divested of privileges and advantages as a public enterprise and with a neutral fare notwithstanding their contribution as common carrier. This would be suited to the principle of liberal market on one hand, not to be freed entirely from countervailing argument on public value as well as paradigm of right to know and freedom of expression. For example, the new policy could incense the adherents of fairness school, who perceive separating the big hands from content creation and dissemination would be a threshold-essentially interwoven with the free flow of ideas and fair opportunity on public issues (Wyatt, 2014). In other words, the contents and application, as said of higher structure of internet, shall be severed from the influence of lower structure of internet, mostly dominant in finance and powerful or backed with the political power. It is prerequisite to ensure the sanctity of internet space, the kind of public forum on various events, stories and issues or agendas, that the telecommunication service will be impartial and dispassionate as well as regulated so as not to be arbitrary or interested to possibly penalize the content businesses. For example, SKT may infringe with the right of consumers if to discriminate the KoreanNaver from Google by assigning a high speed of telecommunication service (Lee, 2015).

However, it is very likely that things will have changed since the internet traffic increased tremendously and even the investment in the internet of things would be no less than frequent. As the legal environment had sharply shifted its landscape, it is natural to follow up with the new norms or reforms of policy and public regulations (Kim, 2015b). The new policy initiative does not appear to bring instantly the pricing policy of internet providers, but it posed the challenge to reconsider the operation or meritocracy and public service of outdated principles or obsolete policy packages. While the Court ruling had affected FCC notably and ensuing state or local policies incidental to a deferential rule of judiciary, the impact could wield an influence within the national market since the FTA between two countries would impose many treaty obligations in terms of non-discrimination. Furthermore, the legal system shared extensively to import 
the US mode of internet regulation. The Department of Creative Economy and Science, inter alia, invoked the FCC regulations into the current frame of public policy on the telecommunication and information services. The KCC (Korean Communication Commission) also would practice largely as same with FCC. The Article 15.7 in FTA also contains same of regulatory measure to the current policy of FTA, which covers the rules on the public access and use of internet for electronic trade (Kim, 2009). The factors would bring a direct consequence on the internet services of South Korea. For instance, the telecommunication services, in tandem, had released a new LTE option of service fee, but restricted the size of data contents with mobile phone (mVoIP), such as Kakaotoc. Years ago, the telecommunication service had disputed with Sam Sung Smart TV (2009).

Nevertheless two countries would differ from several points, but very markedly as supposed in Figure 2. As mentioned, Korean policy emphasized-more than US-the principle of neutrality by granting the status of high speed telecommunication service as common carrier (Yoon, 2010). The policy has long been pursued that unreasonable blocking or discrimination would be prevented effectively. The foundational policy created in 2002 Bush administration assumed that most of telecommunication service would be classed as common carrier in terms of public regulation. This is, of course, because the history of industrial development led to the liberal initiative on market paradigm in US, while the state-led industrialization in Korea generally monopolized the key sectors of infrastructure under the control of national government. The 2005 Court ruling in US would be construed to ascertain the kind of national policies so that subsequent development had been mounting as briefed, although those

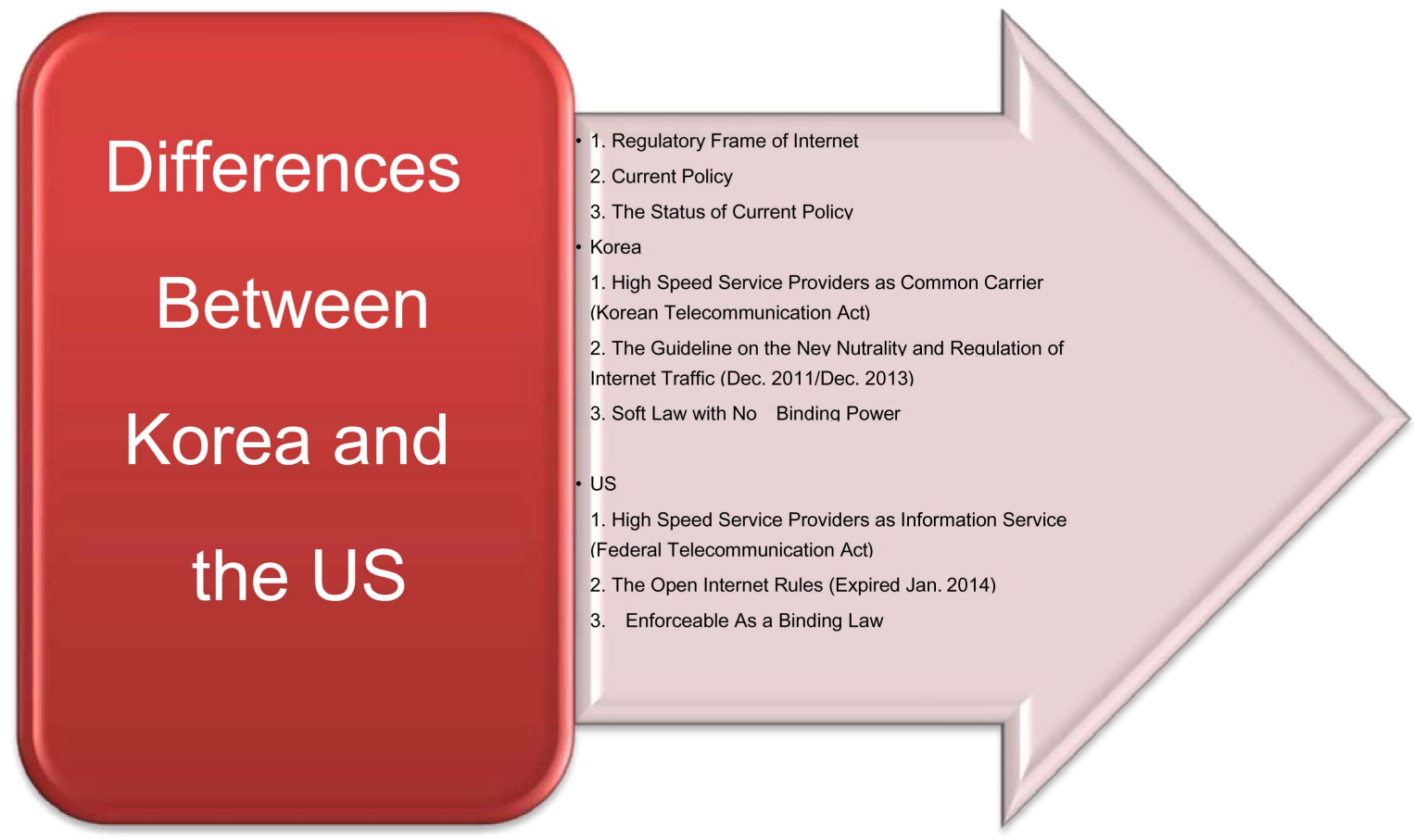

Figure 2. Differences between Korea and US (Source : Korean Communications Commission). 
had never been appealed to the Supreme Court (Editorial Board, 2015). A differing extent of public concern or repercussion from the changing environment of internet would stem from the backdrop of both countries. Korea would generally be less volatile on the regulatory issues while FCC and other public agencies, including the lower courts in US, had been disposed in extensive engagements to seek a better policy. Particularly because the DFCS of Korean government had announced a supplement of policy items on net neutrality in Dec. 2013, we would be unable to receive additional adjustments in the near future. Once again, we are reminded that an important difference underlies the regulatory frame of two countries. While Korea relies on the guideline lacking a binding power to enforce, FCC is empowered to sanction and provides a remedial measure ensuring the compliance of regulatees. Some analyst on this issue commented on the ambiguities and opaqueness of prospect, "The turns of policy would be positive generally, but we would never be comprehensible at this point of time if the telecommunication services had been petered out actually and Korean particulars for policy variants would allow it capricious" (Yoon, 2010).

The statistics in 2013 shows no disparity among the two classes of business in terms of growth in the security market, but the picture changes steadily entering the second period of term. We may infer three possible reasons i) FCC announcement of new policy initiative, ii) globally low interest rates and attraction of dividend as well as defensive strategies of investors, iii) investor's expectation for a large scale merger and acquisition. The trend in businesses is realistic indeed, so that AT\&T planned to merge DirectTV, and Comcast will merge Time Warner cable. Sprint, third in the mobile telecommunication industries, had petitioned for T-mobile. In Europe, Orange had filed for a merger with Bouygues. Although the merger would develop a provision of internet service, one sensitive issue of laws could embroil with the anti-trust laws that calls upon due monitoring or supervision of governmental body (Kim, 2009). Netplix, one competitor against the merger, sent a letter of disagreement to its shareholders specifying that an acquisition of Time Warner cable by Comcast will discourage a competition and increase a subscription and service fee (Ruane, 2013). According to the Wall Street Journal, the supervision authority will not repudiate the kind of trends, and expects a growth of market on the notion of fair competition and welfare of consumers.

\section{Several Policies in US and Comparatively}

The net neutrality is considered to have a growing significance in terms of public regulation that the wide impact of ICT (information and communication technology) has brought an internet-based business (Greenstein, Peitz, \& Valletti, 2016; Kromer, Wiewiorra, \& Weinhardt, 2013; Reggiani \& Valletti, 2016). This accelerates a rate of internet access that inevitably drives it to be a crucial policy issue in response with the welfare of consumers, industrial growth of ICT-related business, as well as the advancement of industrial structure toward the kind of 
creative economy (Staff, 2015). A controversy on net neutrality, hence, needs to focus on two central objectives of public policy, say, a due protection of consumer interests and sustainable development of internet ecology, which could be made feasible with an openness and ecological soundness within the internet community and sustained enhancement of networks. The most prominent challenges in this progress would arise from four important aspects; i) competition became intensified among the players within an increasing kind of ICT markets due to the fusion of network and information technology as developed by All IP or digitalization, ii) the telecommunication services increasingly tend to impose an additional fee for the content providers as stimulated by declined growth or stalemate of small market, iii) the new trend of ICT markets generally necessitates the ISP's right and duty as a gatekeeper of Internet, iv) the enhancement of network quality has to be ensured with the increasing participation and shared sacrifice of various players beyond the telecommunication service, which generates a revenue from the internet business. It needs to be noted that the new internet policy is required to recognize the importance of content producers, which is thought an important class of players that consists of two or three dimensions in this area of public policy (Stiegler, 2012). The horizontal frame of approach perhaps would be a new perspective in addressing the challenges, which alters the vertical one. It is viewed within the horizontal frame that we can identify two or three dimensions of players, which vibrate and boost the ICT economy. In the former, the network providers and content producers are a policy subject, which can leverage in same quality and domain of interest. In the latter, we can identify other independent dimension what we can see as platform. The delicacies between two classifications could influence the shaping of internet policy-especially involved with fair terms of competition and sensibility of economic justice among players (NCTA v. Brand X, 2005).

As viewed, net neutrality actually resulted in the equal treatment of all data packets and no priority delivery should be conceivable among the players as indifferent with contents or terminal application subscribed to the network. The principle was developed in early of new millennium by Tim $\mathrm{Wu}$, and a backlash followed by disagreement from scholars, notably and led by C. Yoo $(2003 ; 2005)$. These scholars use network diversity in highlighting the importance of issue and discriminatory effect of network or telecommunication service. A typical practice to violate the net neutrality would include P2P traffic blocking, restriction on the transmission speed, blocking of mVoIP in 3G net (Kim, 2015). In the extreme, the business practice on tiered internet traded in the commercial purpose may be regarded as to impair the net neutrality. Currently at the center of debate underlies the imposing shift of internet markets, in which the policy makers have to elaborate to resolve the conflict of interest between ISP and 3PP $\left(3^{\text {rd }}\right.$ party player). These players generally pertain to the first classification above, and need to be used expansively to encompass all the interested parties within the internet community. Hence, we could cover the content provider, application 
provider and device provider as 3PP. The imminent needs to upgrade the regulations and to reform a stereotype of traditional policy is not merely hypothetical, but demanded to address the challenges of growing competition of service providers, financial burden to increase a network investment meeting the traffic increase as well as the basic stalemate of telecommunication service and limited available capacities (2015). At the inception of ICT, both players reinforced each other to grow for the current status. Given the complication and growth of markets, the cause to block and discriminate ISP has increased that ISP pursues to legalize a right to manage the traffic-on reasonable commercial order-while 3PP adheres with the neutrality principle and current regulatory regime. ISP basically yields a profit from both of users and 3PP, which currently has transformed with most of profit being generated from users. The new commercial order in Korea, for example, is being discussed to portion the fees of 3PP with the burden of traffic. In the concern, two policy issues arise to govern mVOIP and Smart TV. In Korea, SKT and KT maintain a closed system, in which only fee based subscribers could be allowed to use mVOIP, and perhaps same with LGU+ being implied of fee base. This service is provided by MyPeople, Nateon Toc, Skipe, such 3PP free from the payment of net use on the telecommunication. Since the subscribers can use the service free from charge, the spread of mVOIP would eclipse the revenue base on voice sales against other players. They argue on free ride that $3 \mathrm{PP}$ would be unconscionably profiteering, which is countered by users and 3PP. They urge that it is their right to transmit the data purchased for the mVoIP (2015; Kim, 2009).

The US and Netherland had met these challenges with the reform of act and regulation which banned the blocking of mVoIP by mobile telecommunications, but the international practices seem not uniform. Korean practice is imperfect that a considerable number of mobile telecommunications had compromised to preserve a part of their profit source and to the interest of public. In UK, Vodafone designed the service to allow the subscribers over 41 pounds monthly, and 15 additional user fee is charged otherwise. TMobile, a German corporation, sets the minimum at 49.95 Euros for use, and additional 9.95 Euros has to be paid monthly for other category of users (2015). This business design is same in France, 49 Euros and 15 Euros respectively. One note may be given that the consumer right to opportunities in US seems not satisfactory, although the principle is to mandate a ban of mVoIP blocking. That is because the consumers had to pay the high rate of data use fees at the incident of subscription. Verison requires 69.99 subscription fee and AT\& T 54.99 monthly subscription (2015). In Korea, the controversy has been brought as a civil action by 16 users of mVoIP and in consolidation with the civil activist associations in Oct. 2013. They claimed in the suit that the business practice of KT and SKT violates the Art. 56 of Fair Trade Act, which interferes with the consumer right to opportunities and restrictions of competing service provision. The article provides a basis of tort damages, in case where the businesses and enterprises violate the Act. The plain- 
tiffs invoked two counts of violation, which specifies the abuse of bargaining privilege and prohibition of undue disadvantage. The Mobile telecommunications, of course, would raise contrary viewpoints. For example, it can be asserted that the current business practices a free ride without payment of due compensation for use of net, and they may argue on low subscription fee of users, disruption of their businesses from regulation, burden to the increasing investment needs, as well as consequential detriment to overall welfare of internet community (Yoon, 2010).

\section{Public Policies and Uniform Regulation in Korea}

The consequence of Court ruling ineluctably will lead to an enhanced policy making role on the part of FCC (Kim, 2014b). Several points of legal response can be surveyed, and largely from the comparative view of Korean law on internet regulation. That would not be merely shenanigan, but can provide an example for the federal or state government since the federalism in the US context now resulted in a short of public response other than traditional civil law frame on promotion, damages and criminalization of internet-related crimes (LaFave, 2017). As per the public policy, the Act prescribes several elements so as not to be omitted in creating and implementing policies; i) advancement of net technology and its dissemination, ii) standardization of internet, iii) promotion of content development and use of internet, iv) promotion of common interest in use of internet information, v) protection of personal information and development of technology for that purpose, vi) security and reliability of internet, vii) protection of juveniles and youths. A scope of concern now principled in the Act can be partly derived from the statutes and acts, but general frame seems to be meaningful with assigning a principal duty within the relevant departments or bureaus (AITSPPP, 2015; Yoon, 2010).

For example, the Ministry of Future and Creative Science (MFCS) in Korea is responsible for the research and development, cooperation for or transfer of technology and technology training, which can be seen as distinct in terms of the developmental paradigm of state engagement on this rising sector of national attention. As the neo-protectionism guided, the developed nations, such as US and western countries, also need to keep emulative and on partnership spirit with underdeveloped peers. The research institutions would be funded completely or partially to compensate for the cost of development program, which is internationally permitted as WTO laws exempts from the subsidies category. I can illustrate some of duties according to the elements. First, the MFCS shall be a principal officer, who comprehensively administers on the management of technology and facilities related with the internet (2015). The minister can request pertinent agencies and national or public research institutions for the materials and data relating with the technological information. Unless contrary circumstances are present, the agencies and institutions shall respect his request. Second, the minister shall enforce the public programs and projects to disseminate 
the technological information, which facilitates the immediate and convenient use of it. The standardization of internet is commissioned with the minister, in which he publishes the standard of internet and advises the manufacturers and industries of the use of standard mark (2015). Third, recognition and endorsement can supplant a standardization requirement that the manufacturers and businesses can utilize professional rating agencies appointed by the ministry (2015). Without such recognition and endorsement, they are prohibited from the standard marking or similar impression misleading the consumers. Fourth, the government can provide the financial and technical support for the producers of internet content, which purports to increase national competitiveness and public goodness (2015). The government also can provide the financial and technical support for the national, local agencies and public organizations which developed or operated the applied technology of internet use for efficiency, automation and upgrading of administrative task. The support program can be extended to the private sector, and the government has to breed technicians and professionals to that end, which includes the expansion of internet education and creation or support of educational institutions, and so.

In the standpoint of fair internet access, it seems encouraging that the government has a statutory duty to remove the disparity of internet use and to promote it notwithstanding the residence, sex, and age. The quality control of internet service and increase of common interest for using the internet information through a build-up of supportive system had been prescribed as a ministerial obligation. These provisions principled to mandate the engagement of agencies and ministers had a bearing with the responsible administration and public system of recruitment on open application and contest for the cadre of public offices (2015; Yoon, 2010).

The issue of net neutrality involves the protection of personal information and prevention of intrusion on privacy or defamation. They traditionally had been viewed with the frame of tort damages or civil action, which could curtail a due regulation with public law paradigm. Given it to be unregulated with special acts or decree, the Court should be a principal agency that may occasion a judicial invention for adequate treatment of violation and impairment into privacy or personal honor in the internet space (Kim, 2014c; Yoon, 2010). A public law frame with fines and light imprisonment based on the special act can be more productive, at least, in terms of public policy. A Court rationale with the traditional civil damages is to define both ways as separate and compatible, so that the violators have to be fined and also must be responsible for the tort claims in the civil proceedings. The internet mode of civil lives are disposed in a distinct fashion that the European Court of Justice had recognized the right to be forgotten-the consequence of a specific action in the past contravenes this nature of bestowed right (Directive 95/46/EC, 1995). In 2010, a Spanish citizen lodged a complaint against a Spanish newspaper with the national data protection agency and against Google Spain with the Google Inc. He was disgruntled with the con- 
tinued visibility to the auction notice of his home on Goggle's search although the matter was completely settled years ago. He filed a complaint with the Court requesting to remove or alter the pages in question and to remove the personal data that it could no longer appear in the search results. In its ruling, the EU Court found on three accounts of controversy i) on the territoriality of EU rules, ii) on the applicability of EU data protection rules to a search engine, iii) on the right to be forgotten. On the first account, the court viewed positively to encompass a large and cyber concept of territory-relating to the legal controversy on cyber space. This ruling, therefore, is considered the important judicial invention that legitimatized the applicability of EU rules to Google as illuminated on the second count of issue. The right to be forgotten can be ascertained with the individuals, but under certain conditions-where the information is inaccurate, inadequate, and irrelevant for the purpose of data processing (1995). In allowing the legal remedies, the Court urged a case by case assessment-type of information in question, its sensitivity for the individual's private life and the public interest in having access to that information-and balancing against with other fundamental rights since the right is not absolute. The Google's right to free enterprise, freedom of expression and media had been argued to claim a due consideration, but eventually was not accepted by the Court. On the right to be forgotten, EU had enacted the 1995 Data Protection Directive, in which the right was principled as underpinned over articles, especially in the Article 12 titled the data subject's right of access to data (1995). The need of Directive is considered necessary and proper; i) it needs to be updated and clarified for the digital age, ii) non-European companies, when offering service to European consumers, must apply European rules, iii) effectively reversing the burden of proof to the interest of consumers, iv) effectively dealing with the obligation for a controller who has made the personal data public. The regulatory scheme had been imported to large extent within the Act of Korea, which provides the right to delete his or her personal information in 44.2, for instance. The concept of controller's obligation is to ensure a fair apportionment in terms of internet economy, sociology, public policy and normative challenge (AITSPPP, 2015).

The Act provides that the protection of personal information was spelled out in separate chapter (2) followed immediately by the next chapter (3), which deals with the right of internet users. In Article 27, the providers of telecommunication service are required to appoint the controller, who is responsible to protect the personal information of users and to process the problems or complaints of users on this issue (2015). The providers of telecommunication service shall disclose the policy of personal information when it deals with it and in any convenient manner that the users can readily access it. The providers are obligated to immediately report-the specifics of personal information, the time of leakage, loss and theft, a possible remedy of users, responsive measure of providers, contact point of advice and consultation-to KCC (Korean Communication Commission) or Korean Internet Promotion Agency when it acknowledges a leakage, 
loss, and theft of personal information. Without a due justification, the providers of telecommunication service shall not delay its duty of reporting over more than 24 hours (2014).

\section{Insight and Prospect}

Given the pattern of our public lives in the e-communication age, the net neutrality involves a square aspect of communal interests and impact on the policy areas (Crawford, 2014: pp. 18-23). The role and responsibility of FCC had been challenged by the liberalist cause in US and new enactment on KCC around 2007 had been critiqued by scholars of concern (Yoon, 2010). The content regulation would be debated by broadcasters and producers of cable programs since the national policy should be coherent and integral encompassing all the sorts of public issues. The federalism in US may delimit a Congressional jurisdiction unless it comes within the scope of federal power, which little differs from the unitary scale of national regulation in Korea. The Court opinion, relying on Chevron rule, tends to generally create a feasible policy condition against the challenges that potentially thwart a traditional notion or public value revered to constitute the principle of modern democracy besides the economic policy, as seen with the anti-trust issues and tendency of monopoly (NCTA v. Brand X, 2005). Given the disparity of industrialization history and incongruence depending on the particulars of nations, we may not generalize the consequence of adherence or deference on net neutrality across the national jurisdictions.

Nonetheless, we can share most of its debating points commonly since the e-communication is universal in strands and mode of interplay. Most importantly, the current focus on the technology primacy needs to be revisited to liaison our beliefs and thoughts with the public value we had held. For example, the symptom of Digital Detoxification may be our reality for some civil group and the open access movement or freedom of expression in the cyber space may contest to conflagrate on its public cause. Cyber terrorism or invasion of privacy would be routinely patronized by public officers and legal scholars. We may retrospect our political and public lives by reverting to one modern thinker, J. Hobbes, a contractarian theorist and champion of absolute monarchy (Owen, 2015). His proposition on the social contract and absolute power of sovereign being had altered a pervious paradigm of politics and thought of community, which transformed the central focus of political philosophy from the community to an individual. His philosophy also provoked an importance of sovereign power to protect the life, liberty and property of individuals, hence, the notion of modern democratic theory. A ration and enlightenment ethos had been availed as essential to structure so as to attain two theses simultaneously-the responsible government and freedom of people (Nunziato, 2009: pp. 91-99). The sovereign power is only being to monopolize the political power and violence with legitimacy, and interacts with the ideas of Grotius in establishing the cornerstone of international laws. His idea also could influence the thought of Jean Bo- 
din, as generally being received in more emphasis on nation than international community leading to dualism in understanding the international laws. His thought is precious to understand the cyber space and new political discourse in terms of state regulation (Lachman, 2010: pp. 15-19).

Tim $\mathrm{Wu}$ and Christopher Yoo provide an insight in understanding the current debate on net neutrality $(2003 ; 2005)$. Yoo's view generally would be an anti-neutrality scholar, who, however, would not argue debasing the equal opportunity of net users or content producers, but oppose an interventionist paradigm and more regulatory frame of government (2005). The distrust and antipathy would properly be matched up with a failed image of Leviathan, and historically tasted with the atrocities of two world wars. We would well be known that the kind of post-war thinkers, progressive George Owell and conservative Hayek, had proposed a due response critiquing the monopoly of big and liberal-cause government and abusive power, of course, massively on the capitalism cause (if deregulating or regulating) as well as respect of free contract and liberal market. Yoo's suggestion is simple, but very realistic against the advent of another threat if we insist on the principle of neutrality (2003). From his point of view, the policy makers need to project an evil of monopoly to monstrous telecommunication service, which may go to protect the importance of infrastructure and common public service. It could perhaps be worse than recasting the utility of net neutrality. On the while, Tim $\mathrm{Wu}$, a progenitor of term, "net neutrality" and perhaps his dissenter, stressed a crucial importance of decentralized innovation than central control, as connected with the end-to-end principle or internet of things (2005).

An improvement of telecommunication infrastructure can also be made with the incessant growth of service providers, the kind of decentralized architect on the basic of internet. He illustrated a trending landscape from Yahoo, to Google and through Facebook and Twitter, which would be impossible to consist with the original frame of oligarchy or monolithic control, perhaps same with the telephone and basic common carrier service. The original frame needs to be cautious to hold as a holistic cure that we may flavor on the historic lessons of dynasties and rules of monarchy. The tragedies of coup or rebellions would not be merely an issue of analogy since the same may well be replicated in the prurient interest of enterprises enjoying the status of market dominance. We also can trace examples from history. To say, Bell, now named AT \& T, had collapsed the West Union, and the trust of Edison was overwhelmed by A. Juker, who developed the Hollywood and monopoly of cinema distribution. Beyond the cruelty of economic competition, the failure of net policy also could create a highly problematic challenge that the e-communication is interwoven essentially with the politics, culture, education, and public moral or order of society (Crawford, 2014: pp. 313-320).

\section{Conclusion}

As a prolegomenon, I introduced the importance of internet on the subsistence 
pattern of contemporary lives. Its impact on the civil world is tremendous that informs and networks the global village to any new psychic, social, economic and political morals. Ironically, the world of internet may not guarantee the nobility of humans, but can possibly resurrect a tone of Huguenot or Characterwrought by Samuel Similes at the bottom of human imagery. Otherwise, humans may turn to be a kind of cyborg that would be passive and insipid. I just like to remind the behemoth of Amazon, Facebook, cyber job portals, and many social medias on electronic basis that had risen as a new business success example for the Character side. I also like to remind that a number of book readers turn to resort at the preference of paperback version than electronic one for the Cyborg side. Critiques from the Frankfurt school are to be adverted here as an observer of newly emerging or rapidly growing market called Internet, "the internet and other technological advances are merely another expression of bourgeoisie hierarchy in the civil world." In this paper, I explained the rule and its implications of Brand $X$, and response of interest holders including the government itself, say, President and FCC, as well as the internet related businesses. Given the role of government as a regulator and grey character of due justice on the issues, the internet policy is malleable and frivolously susceptible to the variables on trend, but vitally significant to shape the rule of concerned market area. In other words, the desiderata of legality in this area of policy making is not certain that complicates the policy makers and defers to the extent of economic and social prongs argued by interest holders. In this backdrop, we can understand the position of Brand $V$ court on Chevron rule. The ruling represents an increasing profile of administrative state and importance of expert branches within the executive. For the constitutionalist of democratic experimentalism, it would be welcomed if the court acted on meritocracy by deferring to legislature and FCC, whose policy area actually should be intimate and contagious to the public most powerfully. The ruling thrusts a revival of classic argument on separation of powers principle on one hand and new development of delegation scheme or increasing expert bureaucracies on the other. Through the chapters, I have provided explanations not exhaustively, but comparatively and selectively, in light of the consequence and influence of US policies on the businesses over the global states. I exemplified South Korea particularly involving new uniform regulations on the internet policy. Notwithstanding a specific rule of jurisdictions, the internet business and its impact on the public sphere are never negligible and their presence is the kind of enormity as the chapter Insight and Prospect suggests. Although I have explored the internet and its regulatory issues on principle of net neutrality through Brand $X$ court, the remaining questions are plentiful that subsequent research can contribute. I can suggest some of possibilities here.

First, the issue is essentially intrigued with the first amendment right of US constitutionalism, and some jurisdictions can have different policies at extent and in terms of basic disposition on nations. A comparative study, for example, US and China or Russia, would enable an enhanced understanding of internet 
policy globally.

Second, the internet policy is intersected with the internationalism and signifies the global expansion of market. In terms of law and politics, the international constitutionalism has grown to sympathize with the intelligent circle of global citizenry, who also considers it useful to development of national democracy on the other side of coin. The relationship and requirements can be explicated through the future studies of internet policy beyond economic implications or effect on market.

Third, internet business and telecommunication service constitute a WTO deals on GATS or TRIPs no less than significantly than any other area of businesses. They accounted for the trade dispute involving the US Super 301 and related articles. The business in this area prevailingly would be operated by multilateral corporations. These characteristics bring a scope of complicated legal issues that requires a more systemic and detailed investigation or analysis within the specified frame of respective research.

Forth, the issue or policy area can be developed as if it would be the kind of comparative study on national constitutions because the implications are enormous to vitally govern the public sphere of jurisdictions.

\section{References}

AITSPPP (2015). Act of the Information and Telecommunication Service Promotion and Protection of Privacy. ROK Stat. No. 13285.

Berkman, F. (2014). Title II Is the Key to Net Neutrality—So What Is It? The Daily Dot.

Brand X Internet Servs. v. FCC (2003). 345 F. 3d 1120 (9th Cir.).

Brand X Internet Servs. v. FCC (2006). 2006 U.S. App. LEXIS 1573 (9th Cir., Jan. 23).

Brauer-Rieke, A. K. (2009). The FCC Tackles Net Neutrality: Agency Jurisdiction and the Comcast Order. Berkley Technology Law Journal, 24-1.

Cheng, J. (2009). Comcast Settles P2P Throttling Class-Action for \$16 Million. ArsTechnica (Condé Nast).

Chevron U.S.A., Inc. v. Natural Resources Defense Council, Inc. (1984). 467 U.S. 837. Communications Act of 1934, 48 Stat. 1064

Crawford, S. (2014). Captive Audience: The Telecom Industry and Monopoly Power in the New Gilded Age. New Haven, CT: Yale University Press.

Crenshaw, K. W. (1988). Race, Reform, and Retrenchment: Transformation and Legitimation in Antidiscrimination Law. Harvard Law Review, 1331-1387.

https://doi.org/10.2307/1341398

EU Directive (1995). Directive 95/46/EC on the Protection of Individuals with Regard to the Processing of Personal Data and on the Free Movement of Such Data.

Eveleth, R. (2014). Why Netflix Is "Slowing Down" Its Website Today. The Atlantic.

Federal Communications Commission (2005). New Principles Preserve and Promote the Open and Interconnected Nature of Public Internet. DC: Federal Communications Commission.

Federal Communications Commission (2006). Re: Notice of Ex Parte Communication in the Matter of Review of AT\&T Inc. and BellSouth Corp Application for Consent to Transfer of Control, WC Docket No. 06-74. DC: Federal Communications Commis- 
sions.

Greenstein, S., Peitz, M., \& Valletti, T. (2016). Net Neutrality: A Fast Lane to Understanding the Trade-Offs. The Journal of Economic Perspectives, 30, 127-149. https://doi.org/10.1257/jep.30.2.127

Gross, G. (2015). FCC Votes to Overturn State Laws Limiting Municipal Broadband. CIO Magazine.

Hansell, S. (2008). F.C.C. Vote Sets Precedent on Unfettered Web Usage. New York Times.

Hu, E. (2014). 1 Million Net Neutrality Comments Filed, But Will They Matter? National Public Radio.

Kang, C. (2010). FCC Approves Net-Neutrality Rules; Criticism Is Immediate. The Washington Post.

Kim, C. W. (2015). New FCC Rules on the Net Neutrality. Seoul: Korean Information Society Development Institute.

Kim, D. H. (2009). Two Sided Market Framework for Validity Analysis of Network Neutrality Policy toward the Monopolistic Market Provider. In Studies on the Information and Telecommunication Policy (pp. 1-45). 16-2.

Kim, K. (2014a). The Constitution and Tripartite System of Government: From the Mutiny for the Limited Government through the Interbranch Subtlety. International Journal of Advanced Research, 2, 392-401. https://ssrn.com/abstract=2574711

Kim, K. (2014b). The Relationship between the Law and Public Policy: Is It a Chi-Square or Normative Shape for the Policy Makers? Social Sciences, 3, 137-143.

https://ssrn.com/abstract=2577832 https://doi.org/10.11648/j.ss.20140304.15

Kim, K. (2014c). The Separation of Powers Principle: Is It a Lynchpin or Pushpin for the Voyage of American Public? International Journal of Advanced Research, 2, 887-895. https://ssrn.com/abstract=2573560

Kim, K. (2015a). On the Fundamentals of Law and Public Policy. http://ssrn.com/abstract $=2593758$

Kim, K. (2015b). Public Policy and Governance: Some Thoughts on Its Elements. https://ssrn.com/abstract $=2589526$

Kromer, J., Wiewiorra, L., \& Weinhardt, C. (2013). Net Neutrality: A Progress Report. Telecommunications Policy, 37, 794-813.

Lachman, R. (2010). States and Power. Malden, MA: Polity.

LaFave, W. (2017). Principles of Criminal Law. West Academic.

Lee, S. Y. (2015). Net Neutrality and the Stock Market. http://blog.naver.com/taeun21/220004354658

Lohr, S. (2015). F.C.C. Chief Wants to Override State Laws Curbing Community Net Services. New York Times.

M.H. (2014). Net Neutrality: Faux Go-Slow. The Economist.

McCullagh, D. (2010). Court: FCC Has No Power to Regulate Net Neutrality. CNET.

Nagesh, G. (2014). FCC to Propose New "Net Neutrality” Rules: Proposal Would Allow Broadband Providers to Give Preferential Treatment to Some Traffic. Washington DC: Wall Street Journal.

Nate, A. (2009). FCC Chairman Wants Network Neutrality, Wired and Wireless. New York Times. 
National Cable \& Telecommunications Association (NCTA) et al. v. Brand X Internet Services et al. (2005). 545 U.S. 967.

Nunziato, D. (2009). Virtual Freedom: Net Neutrality and Free Speech in the Internet Age. Stanford, CA: Stanford University.

NYT Editorial Board (2014). Why the F.C.C. Should Heed President Obama on Internet Regulation. New York Times.

Owen, T. (2015). Disruptive Power: The Crisis of the State in the Digital Age. New York, NY: Oxford University Press. https://doi.org/10.1093/acprof:oso/9780199363865.001.0001

Powell, M. (2004). Preserving Internet Freedom: Guiding Principles for the Industry.

Reggiani, C., \& Valletti, T. (2016). Net Neutrality and Innovation at the Core and at the Edge. International Journal of Industrial Organization, 45, 16-27.

Ruane, K. A. (2009). Net Neutrality: The Federal Communications Commission's Authority to Enforce Its Network Management Principles. Congressional Research Service.

Ruane, K. A. (2013). The FCC's Authority to Regulate Net Neutrality after Comcast v. FCC. Congressional Research Service.

Staff (2014). Creating a Two-Speed Internet. New York Times.

Staff (2015). H. R. 114th Congress, 1st Session [Discussion Draft]-To Amend the Communications Act of 1934 to Ensure Internet Openness. U.S. Congress.

Stiegler, Z. (2012). Regulating the Web: Network Neutrality and the Fate of the Open Internet. New York, NY: Lexington Books.

Telecommunications Act of 1996. 110 Stat. 56.

Tim, W. (2003). Network Neutrality, Broadband Discrimination. Journal of Telecommunications and High Technology Law, 2, 141.

http://ssrn.com/abstract $=388863$

Verizon Communications Inc. v. FCC (2002). 535 U.S. 467 (pp. 489-490).

Verizon v. FCC et al. (2014). No. 11-1355 (D.C. Cir.).

Weil, N. (2014). FCC Will Set New Net Neutrality Rules. Computerworld.

WorldCom, Inc. v. FCC (2001). 246 F.3d (pp. 690-692).

Wyatt, E. (2014). Obama Asks F.C.C. to Adopt Tough Net Neutrality Rules. New York Times.

Yoo, C. S. (2005). Beyond Network Neutrality. Harvard Journal of Law and Technology, 19. http://ssrn.com/abstract=742404

Yoon, J. S. (2010). Laws and Public Policy Concerning the Regulation and Promotion of Internet Service Industry. Justice, 121, 732-765. 
Submit or recommend next manuscript to SCIRP and we will provide best service for you:

Accepting pre-submission inquiries through Email, Facebook, LinkedIn, Twitter, etc. A wide selection of journals (inclusive of 9 subjects, more than 200 journals)

Providing 24-hour high-quality service

User-friendly online submission system

Fair and swift peer-review system

Efficient typesetting and proofreading procedure

Display of the result of downloads and visits, as well as the number of cited articles Maximum dissemination of your research work

Submit your manuscript at: http://papersubmission.scirp.org/

Or contact blr@scirp.org 